\title{
Level of Service Research of Public Transport Facilities: A Access of Trivandrum City
}

\author{
Anila Cyril, Raviraj H Mulangi, Varghese George
}

\begin{abstract}
Public transportation is one of the sustainable form of transportation which provides mobility options for the people. The public transport services are very basic need of people's lives, especially in developing world. It is the basic means for mobility of a large percent of people and hence it is the driving force of economic and social life. Quality of service, characterized by the Level-of-Service (LoS) is one of the major factors determining the demand for public transport. This study tries to determine the city-wide Level-of-Service provided by the public transport system using the service level benchmarks as a case study of Trivandrum city. The indicators for determining the Level-of-Service used in the study are presence of organized public transport system, availability or extend of public transport supply, service coverage, average waiting time, level of comfort in public transport and the fleet availability. This approach can be used to determine the LoS at the city-level and thus provides a measure for identifying the public transport quality of an urban area.
\end{abstract}

Keywords: Demand, Level-of-Service, public transport, quality of service.

\section{INTRODUCTION}

India is undergoing rapid urbanization and motorization the past few decades leading to increased travel demand. This increased demand for travel has led to the growth of private vehicles at a rate of $12 \%$ [7]. The share of two wheelers have increased tremendously over the last few decades while the share of buses and goods vehicles are decreasing consistently. There has been an exponential growth of personalized mode of transport during the last two decades. The increase of the personalized mode of transport has led to enormous problems of traffic congestion and pollution besides being a factor for increased number of road accidents. One of the reasons for the growth of the personalized mode of transport is the continuous degeneration in quality of service offered by the public transport system and rising level of expectation of passengers.

The evaluation of service quality is one of the challenging task and an important practical problem encountered by the service providers. The assessment of quality of service is required to improve the user satisfaction and thus to improve the demand for public transport services. Researchers have identified Level-of-Service (LoS) as an

Revised Version Manuscript Received on August 19, 2019.

Anila Cyril, Department of Civil Engineering, National Institute of Karnataka, Surathkal, Mangalore, Karnataka, India. (email: anilacyril110@gmail.com)

Raviraj H Mulangi, Department of Civil Engineering, National Institute of Karnataka, Surathkal, Mangalore, Karnataka, India. (email: ravirajmh@nitk.edu.in)

Varghese George, Department of Civil Engineering, National Institute of Karnataka, Surathkal, Mangalore, Karnataka, India. (email: varghese@nitk.ac.in) effective measure to understand the users' level of satisfaction for the service provided.

The concept of service quality measure using LoS is first introduced in Highway Capacity Manual in 1965 [3]. Later various researchers have revised and modified the concept of level of service to meet the individual needs of highway, freeway, public transport etc. Tyrinopoulos and Antoniou [9] focused the research on level of service based on passenger perception of the performance of the transit. The study dealt with the variability between operators and the policy implications on the user perception.

Polus and Shefer [1] evaluated the level of service of a bus line based on its operational characteristics. It is based on the average travel time using bus and passenger car on the shortest distance between the same origin and destination. Level of service is explained using the explanatory variable like average distance between the bus stations, route length, number of signalized and unsignalized intersections.

Hensher et al. [2] investigated various methods to quantify the service quality and compare the levels within and between the bus operators. The service quality index serves both the operator and the user.

Das and Pandit [6] proposed a methodology to develop an overall framework to determine the threshold LoS based on user perception. Also, they provided a measure to find the maximum number of users from different user segment that will get satisfied at theses threshold LoS values.

\section{STUDY AREA}

Trivandrum, also known as Thiruvananthapuram, is the capital of Indian state Kerala and is an emerging metropolitan city in the southernmost part of India. Thiruvananthapuram district is situated between north latitudes $8^{0} 17^{\prime}$ and $8^{0} 54^{\prime}$ and east longitudes $76^{\circ} 41^{\prime}$ and $77^{\circ} 17^{\prime}$. The city comprises of thickly populated low land and is the most populous and largest city in Kerala with an area of 214.86 sq. km. The city has a population of 1032292 as per census 2011 making it the most populous city in Kerala with an average population density of 4454 persons/sq. km [8]. The growth of urban population is at a rate of 3.25 percent [5]. Trivandrum city corporation area is divided into 100 zones or wards which mark the study boundary. The Trivandrum city is served by three dominant modes of transport- road, rail and air. Of 
these, road network has a wide presence throughout the city. Rail network has a limited but dominating influence and air network has a supplementary role. In Thiruvananthapuram city, the public transport is dominated by state owned Kerala State Road Transport Corporation (KSRTC) buses. Auto rickshaws and taxi cabs are the major intermediate public transport (IPT). Private buses ply on few selected routes but are limited in number. The KSRTC is the single largest public sector undertaking, which carries out passenger transport operations in the State.

\section{DATA COLLECTION}

The data used in this study was collected from KSRTC and National Transportation Planning and Research Centre (NATPAC). The data from KSRTC include the number of public buses (KSRTC buses including JnNURM buses) plying in the Trivandrum city, the details of the routes, bus stops, and schedules. The number of passengers using the buses were obtained from the Electronic Ticket Machine (ETM) data provided by the KSRTC. Additionally, other secondary data like the details of private buses, length of road kilometre, population and urban area limit were collected from NATPAC.

\section{METHODOLOGY}

The Level-of-Service provided by the public transportation facility is determined using the service level benchmarks set up the Ministry of Urban Development [4]. The indicators for determining the Level-of-Service used in the study are presence of organized public transport system,

availability or extend of public transport supply, service coverage, average waiting time, level of comfort in public transport and the fleet availability. This approach can be used to determine the LoS at the city-level and thus provides a measure for identifying the public transport quality of an urban area. The calculation of various indicators of LoS is as follows:

1. Presence of Organized Public Transport System in Urban Area $=$ The total number of buses owned by State Transport Undertakings/ Total number of buses operating in the city

2. Availability of Public Transport $=$ Number of buses available in a city/ Total population of the city

3. Service Coverage of Public Transport in the City = Total length in road kilometers of the corridors on which public transport systems ply in the city/ Area of the urban limits of the city.

4. Average Waiting Time for Public Transport $=$ Half of average headway

5. Level of Comfort in Public Transport = Load factor

The overall city-wide LoS of public transport facilities is the sum of LoS of the indicators from one to five.

\section{RESULTS AND DISCUSSION}

Calculation of various indicators for the public bus service LoS in the city is based on the definitions and specifications given by Ministry of Urban Development (MoUD) [4] as explained in section IV. The indicators for LOS calculations and their ranges as per MoUD is given in Table 1

Table 1: Indicators to Calculate City-Wide Level-of-Service (LoS) of Public Transport Facilities

\begin{tabular}{|c|c|c|c|c|c|}
\hline $\begin{array}{c}\text { Level } \\
\text { of } \\
\text { Service }\end{array}$ & $\begin{array}{c}\text { 1. Presence of } \\
\text { Organized Public } \\
\text { Transport System } \\
\text { in Urban Area (\%) }\end{array}$ & $\begin{array}{c}\text { 2. Extent of } \\
\text { Supply/ } \\
\text { Availability of } \\
\text { Public Transport }\end{array}$ & $\begin{array}{c}\text { 3. Service } \\
\text { Coverage of } \\
\text { Public Transport } \\
\text { in the city }\end{array}$ & $\begin{array}{c}\text { 4. Average waiting } \\
\text { time for Public } \\
\text { Transport users }\end{array}$ & $\begin{array}{c}\text { 5. Level of } \\
\text { Comfort in } \\
\text { Public } \\
\text { Transport }\end{array}$ \\
\hline 1 & $>=60$ & $>=0.6$ & $>=1$ & $<=4$ & $<=1.5$ \\
\hline 2 & $40-60$ & $0.4-0.6$ & $0.7-1$ & $4-6$ & $1.5-2.0$ \\
\hline 3 & $20-40$ & $0.2-0.4$ & $0.3-0.7$ & $6-10$ & $2.0-2.5$ \\
\hline 4 & $<20$ & $<0.2$ & $<0.3$ & $>10$ & $>2.5$ \\
\hline
\end{tabular}

The Table 1 shows various indicators for calculating the LoS of public transport facilities. The first indicator is the presence of organized public transport system in urban area expressed as percentage. If the percentage is greater than or equal to 60, then the $\mathrm{LoS}$ is given a value 'one'. If the value is $40-60 \%$ then, the LoS is two. A $20-30 \%$ presence of public transport means the LoS is three while less than $20 \%$ means $\operatorname{LoS}$ is four. The second indicator used in the study is the availability of public transport. It is the ratio of number of buses per thousand population. The value $>=0.6$ corresponds to LoS1, 0.4-0.6 means LoS2, 0.2-0.4 means LoS3 and $<0.2$ corresponds to LoS4. The third indicator is service coverage of public transport in the city. It is the ratio of length of road kilometers in which public transport is operating to the area of the urban limits of the city. Similarly, LoS of average waiting time and level of comfort in public transport is also determined from Table 1. 
Table 2: Indicator 1. Presence of Organized Public Transport System in Urban Area

\begin{tabular}{|c|c|c|c|c|}
\hline \multirow{3}{*}{ (a) } & \multirow{3}{*}{ The total number of buses operating in the city (B) } & KSRTC & 446 & \multirow{3}{*}{699} \\
\hline & & Private buses & 103 & \\
\hline & & JnNURM & 150 & \\
\hline (b) & $\begin{array}{l}\text { The total number of buses under the ownership of } \\
\text { State Transport Undertakings (A) }\end{array}$ & \multicolumn{3}{|c|}{560} \\
\hline (c) & $\begin{array}{l}\text { Presence of Public Transport System in Urban } \\
\text { Area }(\%)=[\mathrm{B} / \mathrm{A}] \times 100\end{array}$ & \multicolumn{3}{|c|}{80} \\
\hline & LoS1 as per Table 1 & \multicolumn{3}{|c|}{1} \\
\hline
\end{tabular}

The presence of organized public transport system is determined as the percentage of STU buses operating in the city to total number of buses in the city. It was found that 'one'.

Table 3: Indicator 2. Availability of Public Transport

\begin{tabular}{|l|l|l|c|}
\hline (a) & Number of buses available in a city on any day & \multicolumn{2}{|c|}{446} \\
\hline \multirow{2}{*}{ (b) } & \multirow{2}{*}{ Total population of the city } & Census,2011 & 957675 \\
\cline { 3 - 4 } & & Growth rate (Economic Review,2013) & $2.1 \%$ \\
\cline { 3 - 4 } & & Current Population & 997897.4 \\
\hline (c) & $\begin{array}{l}\text { Availability of public transport = [No of Buses available } \\
\text { in a city on any day / Total population of the city }\end{array}$ & \multicolumn{2}{|c}{0.45} \\
\hline & LoS2 as per Table 1 & \multicolumn{2}{|c}{2} \\
\hline
\end{tabular}

The extend of supply or the availability of public transport the city to the number and the total population of the city. The is determined as the ratio of the number of buses available in $\operatorname{LoS}$ for second indicator was found to be '2'.

Table 4: Indicator 3. Service Coverage of Public Transport in the City

\begin{tabular}{|l|l|c|}
\hline (a) & $\begin{array}{l}\text { Total length in road kilometers of the corridors on which public transport systems ply } \\
\text { in the city (Road km) =A }\end{array}$ & 651.35 \\
\hline (b) & Area of the urban limits of the city (Area in sq. $\mathrm{km}$ ) = B & 211.76 \\
\hline (c) & Service Coverage (road km/ sq. km) $=[\mathrm{A} / \mathrm{B}]$ & 3.08 \\
\hline & LoS3 as per Table 1 & 1 \\
\hline
\end{tabular}

The third indicator is the service coverage of public transport in the city. It is the ratio of the total length in road kilometers on which the public transport operates to the urban area limits of the city. The LoS of indicator three is found to be

Table 5: Indicator 4. Average Waiting Time for Public Transport Users'

\begin{tabular}{|c|l|l|}
\hline (a) & $\begin{array}{l}\text { Average headway of buses/route } \\
\text { Calculated for peak hours at the bus stops } \\
\text { Morning: 8:00 }-10: 00 \mathrm{am} \\
\text { Evening: 4:00 }-6: 00 \mathrm{pm}\end{array}$ & 10 minutes (Source: KSRTC schedule data) \\
\hline (b) & Waiting time /route & Half of the average headway $=0.5 * 10=5$ minutes \\
\hline & LoS4 as per Table 1 & \\
\hline
\end{tabular}

The fourth indicator is the average waiting time for public headway details were obtained from KSRTC schedule data. transport determined as half of the average headway. The The LoS of fourth indicator is calculated as ' 2 '.

Table 6: Indicator 5. Level of Comfort in Public Transport

\begin{tabular}{|l|c|}
\hline Passenger comfort level measured based on Load factor (passengers per seat) \\
\hline Load Factor & $0.8 \quad$ (Source: KSRTC) \\
\hline Los5 as per table 5.1 & 1 \\
\hline
\end{tabular}

The fifth indicator is the level of comfort in public transport. This is based on the load factor of the bus. Since the load factor is 0.8 , the LoS of the fifth indicator is ' 1 '.

The overall $\operatorname{LoS}=\operatorname{LoS} 1+\operatorname{LoS} 2+\operatorname{LoS} 3+\operatorname{LoS} 4+\operatorname{LoS} 5$

$$
=1+2+1+2+1=7
$$

Table 7: Overall Level-of-Service of City-Wide Public Transport Facilities

\begin{tabular}{|l|l|}
\hline Overall LOS & Calculated LOS \\
\hline 1 & $<12$ \\
\hline 2 & $12-16$ \\
\hline 3 & $17-20$ \\
\hline 4 & $21-24$ \\
\hline
\end{tabular}

The sum of all the LoS indicators of the public transport facility is 'Seven'. Therefore, the overall LoS is calculated to be 'One'. It can be concluded that the city has a good public transport system. The facilities are available wide spread and 
is available to the people. Thus, the city has a comfortable public transport system.

\section{CONCLUSION}

Quality of service, characterized by the Level-of-Service $(\mathrm{LoS})$ is identified as the major factor determining the demand for public transport. This study determines the city-wide Level-of-Service provided by the public transport system using the service level benchmarks as a case study of Trivandrum city. The indicators for determining the Level-of-Service used in the study are presence of organized public transport system, availability or extend of public transport supply, service coverage, average waiting time, level of comfort in public transport and the fleet availability. This approach can be used to determine the LoS at the city-level and thus provides a measure for identifying the public transport quality of an urban area. The LoS of the indicators are calculated separately and then then overall LoS of the city-wide public transport is calculated as the sum of all the indicators LoS. It is concluded that the city has a good public transport system. The facilities are available wide spread and is available to the people. Thus, the city has a comfortable public transport system.

\section{REFERENCES}

1. A. Polus, and D. Shefer, "Evaluation of a public transportation level of service concept," Journal of advanced transportation, 18(2), 135-144, 1984.

2. D.A. Hensher, P. Stopher, and P. Bullock, "Service quality-developing a service quality index in the provision of commercial bus contracts," Transportation Research Part A: Policy and Practice, vol. 37, no. 6, pp. 499-517, 2003.

3. J. K. Charles, P. Charles, and R. D. Donald, "Highway capacity the level of service concept," $35^{\text {th }}$ Annual Meeting of the Institute of Traffic Engineers, A world traffic engineering conference, Boston

4. Ministry of Urban Development (MoUD), India, "Service level benchmarks for urban transport", NewDelhi: Ministry of Urban Development, Government of India, 2009.

5. Ministry of Urban Development, "Handbook of Urban Statistics", NewDelhi: Ministry of Urban Development, Government of India, 2016.

6. S. Das, and D. Pandit, "Methodology to determine level of service for bus transit in a developing country like India" " In 13th International Conference on Computers in Urban Planning and Urban Management, Faculty of Geosciences, Utrecht University, Utrecht, pp. 2-5, 2013.

7. The Energy and Resources Institute, "Green growth and transport in India”. New Delhi, 2015.

8. Thiruvananthapuram Corporation, "Thiruvananthapuram Master Plan (Draft)", 2012.

9. Y. Tyrinopoulos, and C. Antoniou, "Public transit user satisfaction: Variability and policy implications,". Transport Policy, vol. 15, no. 4, pp. 260-272, 2008. 